\title{
Reflections of a Confluence: International Law in the Philippine Court 1940-2000
}

\author{
Francis Tom Temprosa ${ }^{1}$
}

\section{INTRODUCTION}

In 1901, at the brink of the establishment of a civil government in the Philippines, the present Supreme Court of the Philippines was born. Under American influence, the Philippine Commission instituted a new system modeled after the judicial system of the United States. Judicial powers of government were vested in the Supreme Court and other inferior courts, and the Court was entrusted with the power to issue writs and hear controversies brought before it. ${ }^{2}$

In the same year, one of the very first potential interfaces between international law and municipal law in the country could have happened. The Court was asked to rule on the propriety of the issuance of a writ of habeas corpus in In re the Application of John W. Calloway for a Writ of Habeas Corpus. ${ }^{3}$ Justice Willard wrote that, at that time, no judge was

1 S.J.D. Candidate (Grotius Fellow), University of Michigan, Ann Arbor. Professor of Law, Ateneo de Manila University School of Law; Professorial Lecturer of Public International Law, Far Eastern University Institute of Law; Senior Lecturer of Public International Law, Miriam College; Legal Adviser, Commission on Human Rights of the Philippines.

2 Institute of Developing Economies, The Philippine Judicial System 3 (Raul C. Pangalangan ed., 2001).

3 In re the Application of John W. Calloway for a Writ of Habeas Corpus, G.R. No. 456 (S.C., Aug. 28, 1901) (Phil.). 
conferred with an authority to issue such a writ, and thus, the writ previously issued to free Calloway, who was arrested by virtue of military orders, was repealed. ${ }^{4}$ This started the inexorable march of international law jurisprudence into domestic law.

Years later, during the 1940s, the Court cited international law in a decision involving the freedom and detention of Filipinos who were displaced from their homes by the United States military. In Raquiza v. Bradford, decided in 1945-proximate in time to the Second World War-the Court, in further justifying their detention, said that the Filipinos might be considered as prisoners of war. ${ }^{5}$ It reasoned:

In volume II, Hyde International Law, page 345, section 676, we read:

It should be borne in mind that an army in the field, in the course of any operation in any locality... may also avail itself, of the right to make civilians prisoners of war.

The author cites from the Rules of Land Warfare which contains circumstances under which civilians may be considered as prisoners of war. This enumeration includes:

(c) Persons whose services are of a particular use and benefit to the hostile army or its government, such as the higher civil officials, diplomatic agents, couriers, guides, etc. ... (Emphasis added)

We think that the petitioners would, prima facie, qualify as prisoners of war under the charges of "Espionage activity for Japanese," "Active collaboration with the Japanese," and "Active collaboration with the enemy."

There is a confluence of international law and municipal law on the bed of the Philippine judicial system. There have been ripples in this movement before. But increasingly, through the years, the Philippine Court has referred to international law-and have decided upon questions of international law-on many and different occasions, forming strong currents of disjoint and opposition at times. These movements give rise to implications, as well as questions on the application and operation of international law in the domestic courts of the Philippines.

$4 \quad I d$.

5 Raquiza v. Bradford, G.R. No. L-44, 75 Phil. Rep. 50 (S.C., Sept. 13, 1945) (Phil.).

6 Charles Hyde, International Law Volume II $345 \$ 676$ (2nd ed. 1945). 
This article seeks to provide an overview of such application and operation of international law in the Philippine domestic court. In so doing, it lays down a baseline study on how the court has dealt with international law through cases until 2010. In particular, this article articulates a few observations on the Philippine Court's interpretation of international treaties, treatment and application of customary international law, including the nature of its application, its definition and interpretation in the local setting, the impact of international legal norms on the development of the domestic law, and as a special case, the interpretation of international human rights norms in light of domestic constitutional rules. However, this article by no means presents itself as a comprehensive treatise on the matter.

Before answering those questions, the Philippine legal system and its judiciary must be discussed. This is crucial because the legal system of the Philippines stands unique in its own way, and it is against this backdrop that international law has operated. The judiciary, as an equally unique agent of the government, is the situs of the judge who decides on the application or non-application of international law.

\section{THE BACKDROP AND AGENT OF THE (NON)APPLICATION OF INTERNATIONAL LAW IN PHILIPPINE COURTS}

\section{a. A Hybrid Legal System}

Due to its colonial history, the Philippines has an unusual admixture in its legal system. The Philippines is a democratic and republican State with a mixed civil and common law tradition. Primarily, Philippine law is based on the Spanish civil legal tradition. It has been, however, heavily influenced by the United States' common law tradition, while Shari'ah law (personal law) applies to Muslims. ${ }^{7}$ The Philippines acquired the common law system from the United States, and the civil law system from Spain. ${ }^{8}$ This resulted in the current hybrid system, but it is still largely rooted in the civil law tradition.

7 Soliman M. Santos, Common Law Elements in the Philippine Mixed Legal System, 2 Australian Journal of Asian Law 34 (2000).

8 Miriam Defensor-Santiago, International Law: With Philippine Cases and Materials, And ASEAN Instruments 31 (1999). 
Villanueva has opined that because of the mixed legal traditions, the Philippine legal system bears the underlying philosophies of the principle of stare decisis of the common law system, and the evolving principles of judicial precedents of the civil law system. ${ }^{9}$ As background, he writes that the Philippines has been subjugated, Christianized, and governed by Spain for more than 350 years until the end of the 19th century, and then further subjected to four decades of American domination. ${ }^{10}$ This blend of diverse cultures causes a unique hybrid legal scenario. The geographic location of the Philippines largely contributes to this uniqueness because the nation lies strategically as the gateway to and from Southeast Asia into the Pacific Ocean. ${ }^{11}$ The legal system is full of "elasticity and progressiveness" as the two great western legal systems confluence. ${ }^{12}$

Others have regarded the amalgam as having a unique blend of not only civil law (Roman) and common law (Anglo-American), but also of Muslim (Islamic) and indigenous law. ${ }^{13}$ This is due to the presence, as stated above, of Shari'ah law in the system and some form or recognition of indigenous justice. ${ }^{14}$ Also, there had been desire to refashion the Philippine legal system to conform to the Filipino way and to make it responsive to the nation's needs. ${ }^{15}$ Additionally, just as other developing countries, the

9 Cesar Lapuz Villanueva, A Comparative Study of the Judicial Role and its Effect on the Theory on Judicial Precedents in the Philippine Hybrid Legal Systems, 65 Philippine Law Journal 42, 45 (1990).

10 Id. at 42 (citing Pascual, The Legal System of the Philippines 7 (1970)).

11 Id.

12 Id.

13 Milagros Santos-Ong, Part 2: Philippine Legal Information Resources and Citations, Hauser Global Law School Program (Mar. 2015), http://www.nyulawglobal. org/globalex/philippines1_part2.htm\#Aviii2.

14 See The Indigenous Peoples Rights Act, Rep. Act No. 8371, \$15, (Oct. 29, 1997) (Phil.) ("Justice System, Conflict Resolution Institutions and Peace Building Processes.- The ICCs/IPs shall have the right to use their own commonly accepted justice systems, conflict resolution institutions, peace building processes or mechanisms and other customary laws and practices within their respective communities and as may be compatible with the national legal system and with internationally recognized human rights.").

15 Villanueva, supra note 9 , at 43. 
Philippines faces the challenge of developing its legal system into a more logical and structurally coherent one that is responsive to the complex needs of its diverse society. ${ }^{16}$ In all these, there was, however, a warning by Laurel in the 1930s of great confusion as the "cross-breeding of the Castilian lion and the American eagle had resulted in the evil birth of a phenomenal creature."17

As far as international law and its application in Philippine courts are concerned, Defensor-Santiago confirms that the unusual admixture in the legal system leads to the present constitutional provision that relates to international law. ${ }^{18}$ This constitutional provision, as discussed below (see, discussion infra Part 4.b), directly prescribes the relation between domestic law and international law. This bears an impact on how the courts have perceived international law and has applied the same. Feliciano makes a legal theory that Philippine internal or civil law is a formally complete system so that it enjoins the use of alternative bases for legal decisions (i.e., customary law and general principles of law). In short, there is no problem of non-liquet in internal law. ${ }^{19}$ There is always a rule or standard that applies to every controversy.

\section{b. The 'Gatekeeper' Judiciary and Cases on International Law}

A judicial system already existed in the Philippines prior to the Spanish conquest of the Philippines. ${ }^{20}$ During the Spanish rule, courts consisted of superior courts and inferior or lower courts. Appointments to the superior courts or Audencia were made by the King through a royal decree. Usually, the Governor General, who was the presiding officer, was given the power to appoint judges of lower courts and even to fill in the Audencia. ${ }^{21}$ As pre-

$16 \quad I d$.

17 Id. at 42-43 (citing Laurel, Assertive Nationalism 80 (1931)).

18 Defensor-Santiago, supra note 8.

19 Florentino Feliciano, On the Functions of Judicial Review and the Doctrine of Political Questions, 39 Philippine Law Journal 444, 455 (1964) (citing Civil Code, $\$ 9-11$, Rep. Act 386 (Phil.)).

20 Institute of Developing Economies, supra note 2, at 1.

21 Id. at 2 (citing Jose R. Bengson, The Philippine Judicial System 6). 
viously mentioned, the present judicial system was organized and formed with the advent of the American period. Changes occurred years after.

At present, under the regime of the 1987 Constitution, judicial power is vested in one Supreme Court and in such lower courts as may be established by law. This power includes "the duty of the courts of justice to settle actual controversies involving rights which are legally demandable and enforceable, and to determine whether or not there has been a grave abuse of discretion amounting to lack or excess of jurisdiction on the part of any branch or instrumentality of the Government." ${ }^{22}$ Congress has the power to define, prescribe, and apportion the jurisdiction of courts, but may not deprive the Supreme Court of jurisdiction over certain cases. ${ }^{23}$ One of those powers directly relates to international law: the power to review on appeal or certiorari, as the law or Rules of Court may provide, final judgments and orders of lower courts in cases in which the constitutionality or validity of any treaty, international or executive agreement is in question. ${ }^{24}$

What comes out of this is the natural predisposition of the Court to uphold the Constitution above all. It is the ultimate litmus test of the validity of an act, such as a treaty. It is but natural since as a domestic court, it applies-first, foremost, and solely in many times-domestic law.

The high court already held this power of judicial review even before the 1987 Constitution; the 1935 Constitution had authorized the court to review all cases in which the constitutionality or validity of any treaty, law, ordinance or executive order, or regulation was in question. ${ }^{25}$ Feliciano refers to judicial review as the "assaying by a court," in an appropriate case, of the constitutional quality of a legislative or executive act. ${ }^{26} \mathrm{He}$ suggests that at least three functions are performed by the Supreme Court in judicial review: the checking function, the legitimating or validating function, and the symbolic or educational function..$^{27}$ The first, namely, the checking function, is to read the constitutional map and to allocate the constitutional

22 Const. (1987), art. VIII, sec. 1 (Phil.).

23 Id. art. VIII, sec. 2.

24 Id. art. VIII, sec. 5(2)(a).

25 Const. (1935), art. VIII, sec. 2(1) (Phil.).

26 Feliciano, supra note 19, at 444.

$27 \quad I d$. 
authority among major structures of the government. ${ }^{28}$ The second, namely the legitimating or validating function, indicates that the courts' sustaining of an act or refraining from ruling on it, is equivalent to legitimating the act. Of course, the court's power involves the power to reject the act as illegitimate. ${ }^{29}$ The third, namely the symbolic or educational function, happens when the Supreme Court discharges the parameters of when the court acts as the "pronouncer and guardian" of the more fundamental values that the community seeks. ${ }^{30}$

In the realm of foreign relations, Bernas notes that most framers of the 1935 Constitution worked from the perspective of what they know of foreign relations in the United States. ${ }^{31}$ They captured the essence of the allocation of foreign relations powers from the American perspective. ${ }^{32}$ Foreign relations are thus conducted by political departments, Congress and the executive President, or through the President's bureaucracy. ${ }^{33}$

Does the judiciary, particularly the Supreme Court, have any role in this? Bernas rejoins that the Court has original jurisdiction over cases affecting ambassadors, other public ministers, and consuls. ${ }^{34}$ More importantly, courts can affect the course of foreign involvements through its aforementioned power of judicial review. ${ }^{35}$ When an official act is declared unconstitutional (invalid), the impact could be far reaching because the act becomes unenforceable in domestic law. Internationally, when it involves a treaty, the State is "faced with having an international obligation without the possibility of hiding behind an assertion of unconstitutionality." 36 This is because as we know, the Vienna Convention on the Law of Treaties provides, in Article 27, that a party may not invoke internal law as a justi-

\footnotetext{
28 Id.

29 Id. at 448.

$30 \quad$ Id. at 450.

31 Joaquin G. Bernas, Foreign Relations in Constitutional Law 100 (1995).

32 Id.

33 Id. at 122.

34 Id.; see Const. (1987), art. VIII, sec. 5(1) (Phil.).

35 BERnAs, supra note 31.

36 Id.
} 
fication for failure to perform a treaty. ${ }^{37}$ Moreover, Malaya says that when the Court decides to act, far-reaching consequences include ordering the executive branch to renegotiate an implementing agreement. ${ }^{38}$

In practice, the Court is most hesitant in nullifying foreign relations actions (e.g., concluding treaties and executive agreements). ${ }^{39}$ People's Movement for Press Freedom v. Manglapus explained this reticent attitude. ${ }^{40} \mathrm{It}$ stated as follows: "[t]he conduct of foreign relations of our Government especially the sensitive matter of negotiating a treaty with a foreign government is lodged with the political Departments of the government... the propriety of what may be done in the exercise of their political powers is not subject to judicial inquiry." ${ }^{41}$

For instance, when called upon to rule on an apparent conflict between international and municipal laws, as shown in cases below, the Court has tried to harmonize treaties with domestic law in cases of conflict. Some scholars argue that this hesitation to render these foreign relations acts as invalid or unconstitutional confuses the dichotomy between international law and municipal law in jurisprudence.

In Bayan v. Zamora, the court considered the question of whether the constitutional requirement that the treaty, the Visiting Forces Agreement with the United States, be "recognized as a treaty by the other contracting state," has been met. ${ }^{42}$ To recall, after the expiration in 1991 of the agreement between the Philippines and the United States on military bases, foreign military bases, troops or facilities were not allowed in the Philippines except under a treaty duly concurred by the Senate and, when the Congress so requires, ratified by a majority of the votes cast by the people in a national referendum held for that purpose, and recognized as a treaty

37 Vienna Convention on the Law of Treaties art. 27, May 23, 1969, 1155 U.N.T.S. 331, 8 I.L.M. 679.

38 J. Eduardo Malaya, Conflict and Cooperation in the Crafting and Conduct of Foreign Policy, 55 Ateneo Law Journal 126, 138 (2010).

39 Bernas, supra note 31, at 123.

40 Peoples Movement for Press Freedom v. Manglapus, G.R. No. 84642 (S.C., Sept. 13, 1988) (Phil.).

$41 \quad I d$.

42 Bayan v. Zamora, G.R. No. 138570, 342 S.C.R.A. 449 (Oct. 10, 2000) (Phil.). 
by the other contracting State. ${ }^{43}$ The bone of contention was the character of the agreement, which was undoubtedly an executive agreement. The Supreme Court, however, sustained the executive agreement as a treaty, which satisfies the constitutional requirement, citing the definition of treaty in the Vienna Convention on the Law of Treaties. ${ }^{4}$

Magallona asserts that Bayan transports the meaning of "treaty" to the international plane, shifting the paradigm from the law of treaties under the Constitution to the law of treaties in objective international law. ${ }^{45}$ Evident from the Constitution is the intent to disallow executive agreements as means of concluding agreements on the visit of foreign troops. For Magallona, there was a double shift: (1) the first shift is the interpretation of the term "treaty" from its constitutional meaning to its "ordinary" meaning; 46 and (2) the second shift is the transference of the interpretation of the concept of "treaty" from the national law to objective international law. ${ }^{47}$

There have been spirited dissents on this and other similar cases. ${ }^{48}$ Azcuna quotes the strong dissent by Chief Justice Puno which points out that the framers of the Constitution precisely wanted to end the "analogous asymmetry" in treaties of the past when the other State signed a mere executive agreement. ${ }^{49} \mathrm{He}$ contends that executive agreements are not as binding as treaties under international law. ${ }^{50}$

Nonetheless, the hesitation of the Court is not without legal basis since the caution is built into the present Constitution. Bernas states that the power of judicial review is extended to the determination of "whether or not there has been a grave abuse of discretion amounting to lack or excess of jurisdiction on the part of any branch or instrumentality of the

\footnotetext{
43 Const. (1987), art. XVIII, sec. 25 (Phil.).

44 Bayan, G.R. No. 138570.

45 Merlin M. Magallona, The Supreme Court and International Law: Problems and Approaches in Philippine Practice, 85 Philippine Law Journal 1 (2010).

$46 \quad I d$. at 10.

$47 \quad I d$.

48 Malaya, supra note 38, at 142.

49 Adolfo S. Azcuna, The Supreme Court and Public International Law, 46 Ateneo LAW Journal 24, 27 (2001).

$50 \quad I d$.
} 
Government." 51 The Court's description of grave abuse of discretion-for example, as capricious and whimsical exercise of judgment as is equivalent to lack of jurisdiction-narrows down what Bernas calls the "playing room for judicial action." The Court would more likely apply the political questions doctrine to bar itself from ruling on contentious issues. ${ }^{52}$

Additionally, since the final decision on disputes and cases rests upon the Court, it holds in its hands the key to determine whether a particular rule in international law becomes part of the domestic legal system, thereby capable of being applied by the Court. Almost always, the Court refers to the Constitution in its determination, particularly the provision that directly prescribes the relation between domestic law and international law. Evidently, international law per se is rarely, or almost never, directly utilized in inferior domestic courts.

Indeed, the judiciary in the Philippines has played a definitive role throughout the years. Laws and jurisprudence since the first Philippine Republic are applicable until they are repealed or superseded. ${ }^{53}$ Under the Civil Code of the Philippines, judicial decisions applying or interpreting the laws or the Constitution form part of the Philippine legal system. ${ }^{54}$ Scholars assert that the courts have a role of creation in society. This creative role and the underlying theory on judicial precedents are attributable to five factors: (1) the adoption of the American court system; (2) the constitutional powers vested in the Supreme Court; (3) the transplant of Anglo-American principles in the Philippine legal system; (4) the continuing influence of civil law; and (5) the cultural, social, and economic demands of Philippine society. ${ }^{55}$ These are the factors that influence the Philippine theory on judicial precedents.

The judiciary is the passive branch of Philippine government, or the least dangerous branch among the three. But, if and when it does act on matters of foreign affairs, the impact is ample, ${ }^{56}$ even drastic and disconcerting.

51 Bernas, supra note 31, at 122; see also Const. (1987) art. VIII, sec. 2(1) (Phil.).

52 BERNAS, supra note 31, at 123-24.

53 Santos-Ong, supra note 13.

54 Civil Code, $\S$ 10, Rep. Act 386, as amended (Phil.).

55 Villanueva, supra note 9 , at 45.

56 Malaya, supra note 38, at 141. 


\section{A BRIEF VIEW OF INTERNATIONAL LAW CASES IN THE PHILIPPINE COURT THROUGH THE YEARS}

What areas or themes in international law has the Supreme Court dealt with, directly or indirectly? In 2001, Azcuna surveyed leading cases decided by the Court from 1945 to 2000 pertaining to international law. Two general observations were made: (1) that the Court adopts a situational approach of developing the law through a changing factual environment; and (2) that primacy is given to the Constitution, with special attention to the provision that "the Philippines adopts the generally accepted principles of international law as part of the law of the land." 57

Cases cited in this section are not a comprehensive list of decisions pertaining to international law during the respective periods below. Rather, they are presented only for the purposes of this paper.

\section{a. $1940 \mathrm{~s}$ to $1950 \mathrm{~s}$}

In the 1940 s to the early 1950 s, decisions had principles, such as the privilege of extraterritoriality of a liberating army, the Hague Resolutions and the impact of war on private property, as issues therein. The treatment of an alien brought in by the belligerent occupant as a spy was also at issue. ${ }^{58}$ It was understandable as the country was then reeling from the effects and incidents of the Second World War. These were concerns arising from the war. But Azcuna stated that the case of the alien spy paved the way for the opening up of international human rights law. ${ }^{59}$

Lockwood explains that, as might be expected, the Second World War opened a Pandora's Box of legal troubles in the Philippines. ${ }^{60}$ The Government struggled to solve the problems resulting from the war. ${ }^{61}$ The bench was confronted with problems that involved questions of municipal law

\footnotetext{
57 Azcuna, supra note 49, at 26 (citing Const. (1987) art. II, sec. 2 (Phil.)).

$58 \quad I d$.

$59 \quad I d$.

60 L.D. Lockwood, The Philippine Supreme Court and Postwar Problems of International Law, 3 STANFORd Law Review 3, 3 (1950).

$61 \quad I d$.
} 
only, while others involved that of international law. ${ }^{62}$ The most important ones, however, are purely international law questions, a subject which the Philippines had little to do with in the past. ${ }^{63}$

In Raquiza v. Bradford, the Court ruled that it had no jurisdiction over the United States Army since a foreign army permitted to march through a friendly country or to be stationed in it, by permission of its government, was exempted from civil and criminal jurisdiction of the hosting nation. ${ }^{64}$ Dissents argued that the Army was not foreign since the Philippines was then under American sovereignty. ${ }^{65}$ During the Japanese occupation, Haw Pia v. China Banking Corporation upheld the confiscation of movables belonging to the State susceptible of military use or occupation. ${ }^{66} \mathrm{~A}$ bank was declared as an enemy as it was controlled by enemies of Japan and incorporated in a country at war with Japan. ${ }^{67}$ Dissents opined that private property should be protected. ${ }^{68}$ Contrary to Haw Pia, the Court in Lo Ching Y So Sun Chong Co. enunciated the doctrine that a belligerent army had no right to confiscate private property in the territory invaded. ${ }^{69}$

Of particular note at this time is the 1949 case of Koroda v. Jalandoni, where the Court declared that the rules and principles of land warfare, contained in the Hague and Geneva Conventions, became a part of Philippine law via the incorporation clause in the Constitution. ${ }^{70}$ Chief Justice Moran reasoned that the Constitution was general and extensive, and did not confine the recognition of international law rules to only those in treaties under which the Philippines is a party. ${ }^{71}$

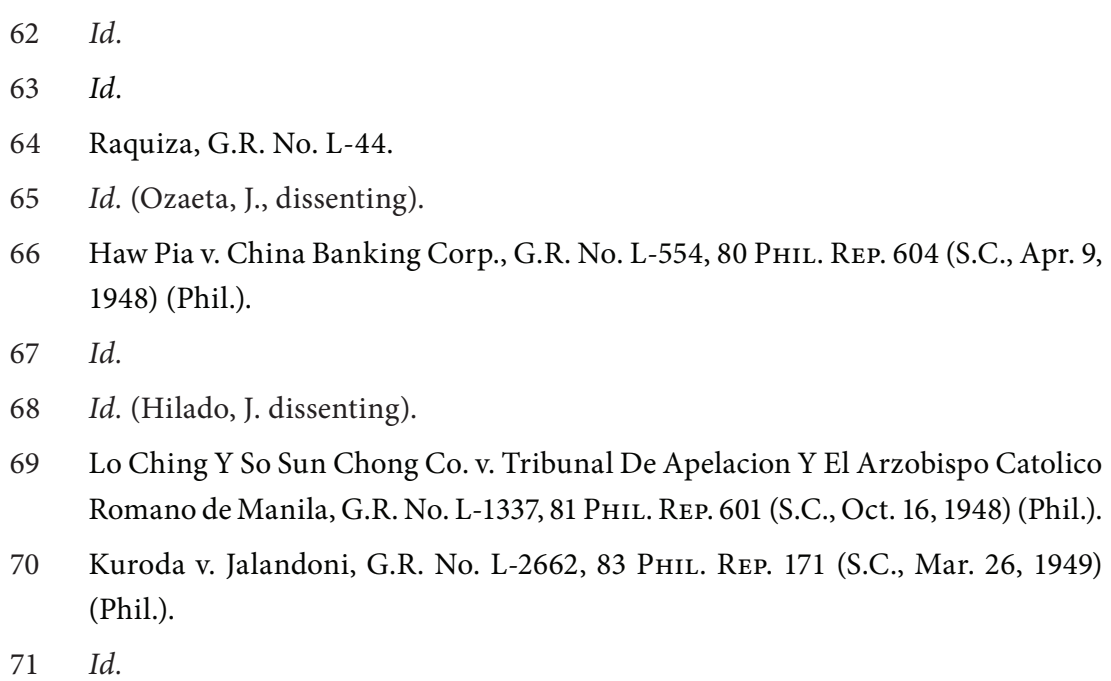


Moreover, in Gibbs v. Rodriguez, the Court noted that decisions of municipal tribunals were subsidiary means for the determination of the rules of international law, citing Article 38(1) of the Statute of the International Court of Justice. ${ }^{72}$ Courts are organs of the State which generally proclaims what it believes international law is. Furthermore, Mejoff v. Dir. of Prisons, a landmark habeas corpus case concerning the detention of a stateless person, referred, inter alia, to the incorporation clause in the 1935 Constitution (see below) and the Universal Declaration of Human Rights (UDHR) in finding that no one should be subjected to arbitrary arrest, detention or exile. ${ }^{73} \mathrm{~A}$ few years later, however, the Court ruled in Inchong $v$. Hernandez that the Declaration contained nothing more than a mere recommendation or a common standard of achievement for all peoples and nations. ${ }^{74}$

\section{b. 1950 s to $1990 \mathrm{~s}$}

Azcuna describes the Court of this time as charting a course through international obligations and national exigencies. An example of national importance is the case relating to the nationalization of retail trade. Other issues include the recognition of relations with other States, scope of treaties on practice of professions, sovereign immunity from suit of foreign States and specialized international agencies, and the interpretation of the Warsaw Convention on International Carriage by Air. ${ }^{75}$

Questions affected trade and commerce. In Inchong, a statute on retail trade nationalization was questioned for violation of treaties and international obligations, and the Court held that the UN Charter imposed no strict or legal obligations with regard to rights and freedoms of international actors. ${ }^{76}$ And, as previously mentioned, the UDHR contained mere recom-

72 Gibbs v. Rodriguez, G.R. No. L-1494, 84 Phil. Rep. 230 (S.C., Aug. 3, 1949) (Phil.).

73 Mejoff v. Dir. of Prisons, G.R. No. L-2855, 90 Phil. ReP. 70 (S.C., July 30, 1951) (Phil.).

74 Inchong v. Hernandez, G.R. No. L-7995, 101 Phil. Rep. 1155 (S.C., May 31, 1957) (Phil.).

75 Azcuna, supra note 49, at 26-27.

76 Inchong, G.R. No. L-7995. 
mendations or common standards of achievement. ${ }^{77}$ Gonzales v. Hechanova involved rice and corn importation through executive acts and contracts with Vietnam and Burma. ${ }^{78}$ Asaali v. Comm'n of Customs declared that customs laws applied to Philippine ships even outside Philippine territory. ${ }^{79}$

There were issues on immunity. For example, World Health Org. v. Aquino held that where the plea of immunity was recognized and affirmed by the executive branch, the Court had to accept the immunity claim. ${ }^{80} \mathrm{It}$ would not embarrass the executive. Other cases ruled that immunity from suit was inapplicable where a State entered into a contract of commercial nature ${ }^{81}$ that the doctrine of State immunity from a lawsuit was not applicable to unauthorized acts for which private responsibility was sought; ${ }^{82}$ and that immunity was also inapplicable to private acts. ${ }^{83}$

A special note on Int'l Catholic Migration Comm'n v. Calleja is in order. ${ }^{84}$ Like the case on immunity from local jurisdiction, the Intl'l Catholic Migration Comm'n case determined whether the right of labor to petition for certification election was availing alongside claims of diplomatic immunity. ${ }^{85}$ It is also an application of the incorporation clause in the Constitution.

In a Memorandum of Agreement with the International Catholic Migration Commission (ICMC), the government granted ICMC the sta-

$77 \quad I d$.

78 Gonzales v. Hechanova, G.R. No. L-21897, 9 S.C.R.A. 230 (S.C., Oct. 22, 1963) (Phil.).

79 Aasali v. Comm'r of Customs, G.R. No. L-24170, 26 S.C.R.A. 382 (S.C., Dec. 16, 1968) (Phil.).

80 World Health Org. v. Aquino, G.R. No. L-35131, 48 S.C.R.A. 242 (S.C., Nov. 29, 1972) (Phil.).

81 United States v. Guinto, G.R. No. 76607, 182 S.C.R.A. 644 (S.C., Feb. 26, 1990) (Phil.).

82 Shauf v. Court of Appeals, G.R. No. 90314, 191 S.C.R.A. 713 (S.C., Nov. 27, 1990) (Phil.).

83 Minucher v. Court of Appeals, G.R. No. 97765, 214 S.C.R.A. 242 (S.C., Sept. 24, 1992) (Phil.).

84 Int'l Catholic Migration Comm'n v. Calleja, G.R. No. 85750, 190 S.C.R.A. 130 (S.C., Sept. 28, 1990) (Phil.).

85 Id. 
tus of a specialized agency with corresponding diplomatic privileges and immunities ${ }^{86}$ The Department of Foreign Affairs (DFA) supported the claim of immunity and held that an order to hold certification election violates this immunity. ${ }^{87}$ The Court ruled that specialized agencies are international organizations with functions in particular fields. ${ }^{88}$ ICMC enjoyed immunity as necessitated by its international character and recognized purposes. ${ }^{89}$ Besides, the labor organizations had recourse to resolve disputes with management. ${ }^{90}$

According to Magallona, a number of points militate against this. First, international organizations characterized as persons in law are intergovernmental organizations; the States establishing it in a multilateral treaty comprise its membership. ${ }^{91}$ ICMC, a non-governmental organization although international, was not created under international law as an international person. ${ }^{92}$ It is a private corporation composed of individuals. ${ }^{93}$ Second, it is through the Memorandum of Agreement that ICMC acquired its "status of a specialized agency" or "similar to that of a specialized agency." Third, it is intriguing how the government can create a specialized agency out of ICMC by means of a Memorandum of Agreement and conjure unilaterally its coverage under the Convention on Specialized Agencies. ${ }^{95}$ Fourth, despite the pretense that the Philippine government is capable of granting the status of specialized agency as well as "diplomatic privileges and immunities" by agreement, the problematic Memorandum of Agreement is devoid of legal status. ${ }^{96}$ Other cases on the alleged confusion as to

\begin{tabular}{ll}
\hline 86 & Id. \\
87 & $I d$. \\
88 & $I d$. \\
89 & $I d$. \\
90 & $I d$. \\
91 & Magallona, supra note 45 , at 75. \\
92 & Id. at 76. \\
93 & Id. \\
94 & $I d$. \\
95 & $I d$. at 78. \\
96 & $I d$.
\end{tabular}


diplomatic immunity with international immunity were cited, ${ }^{97}$ such as Lasco v. UN Revolving Fund for Natural Resources Exploration, ${ }^{98}$ Dep't of Foreign Affairs $v$. Nat'l Labor Relations Comm'n, ${ }^{99}$ and Se. Asian Fisheries Dev. Ctr.-Aquatic Dep't v. Nat'l Labor Relations Comm'n. ${ }^{100}$

\section{c. 1990 s to 2000 s}

During this time, according to Azcuma, cases dealt with the environment and human rights, and extradition. ${ }^{101}$ The question of the Visiting Forces Agreement with the United States was also at issue. Landmark cases include Laguna Lake Dev. Auth. v. Court of Appeals, which held in part as ratio that the right to health was a human right. ${ }^{102} \mathrm{Of}$ course, there is the case of Oposa v. Factoran on intergenerational responsibility. ${ }^{103}$ These and other cases on the interface of international human rights law with municipal law are discussed in more detail in Part 4.d. As for extradition, Sec'y of Justice v. Lantion ruled that there was no right to notice and hearing during the evaluation stage of an extradition proceeding. ${ }^{104}$

Azcuna's categorization of the periods in which the Supreme Court of the Philippines have referred to, or decided upon, certain topics relating to international law, is by no means neat and exclusive of other topics within each epoch. It, however, provides an overall picture of how the court has applied international law given the changing discourses in Philippine society through the years.

97 Id. at 81-85.

98 Lasco v. UN Revolving Fund for Natural Res. Exploration, G.R. Nos. 109095109107, 241 S.C.R.A. 681 (S.C., Feb. 23, 1995) (Phil.).

99 Dep't of Foreign Affairs v. Nat'l Labor Relations Comm'n, G.R. No. 113191, 262 S.C.R.A. 39 (S.C., Sept. 18, 1996) (Phil.).

100 Se. Asian Fisheries Dev. Ctr.-Aquatic Dep't v. Nat'l Labor Relations Comm'n, G.R. No. 86773, 206 S.C.R.A. 283 (S.C., Feb. 14, 1992) (Phil.).

101 Azcuna, supra note 49.

102 Laguna Lake Dev. Auth. v. Court of Appeals, G.R. No. 110120, 231 S.C.R.A. 292 (S.C., Mar. 16, 1994) (Phil.).

103 Oposa v. Factoran, G.R. No. 101083, 224 S.C.R.A. 782 (S.C., July 30, 1993) (Phil.).

104 Sec'y of Justice v. Lantion, G.R. No. 139465, 322 S.C.R.A. 160 (S.C., Jan. 18, 2000) (Phil.). 
It must be noted that the Court has consistently grappled with the questions on the relationship between international law and municipal law (including the treatment of customary norms) and treaty interpretation. And, these are discussed in Part 4 below.

\section{d. 2000 s to 2010}

The variety of the topics on international law discussed by the Court took on new heights during this decade. There was an increase in the number of cases interfacing international human rights law with municipal law (see Part 4.d). Likewise, the Court made pronouncements on the ratification of treaties and pacta sunt servanda. A case involved the extent of the power of the President in pursuing the peace process and other novel questions in international law. Questions in miscellany included obligations related to corruption and transnational crime, and again, the Visiting Forces Agreement between the Philippines and the United States.

Cases dealt with treaty law. In Pimentel v. Exec. Sec'y, petitioners filed a petition for mandamus to compel the Office of the Executive Secretary and the DFA to transmit the signed copy of the Rome Statute of the International Criminal Court to the Senate of the Philippines for its concurrence pursuant to the Constitution. ${ }^{105}$ It was claimed that ratification of a treaty, under both domestic and international law, was a function of the Senate, hence it was the duty of the executive to transmit the signed copy to the Senate to allow it to exercise its discretion. The Court, however, citing the President's role as the sole organ and authority in external relations, said that it was not a ministerial duty to transmit the copy. ${ }^{106}$ Abaya v. Ebdane considered a provision in domestic law as embodying the fundamental principle of pacta sunt servanda. ${ }^{107}$ The case involved a loan agreement between Japan and the Philippines. ${ }^{108}$

One case involved a peace agreement and other novel issues in this jurisdiction. There were several pronouncements in Province of N. Cotabato

105 Pimentel v. Exec. Sec’y, G.R. No. 158088, 462 S.C.R.A. 622 (S.C., July 6, 2005) (Phil.).

106 Id.

107 Abaya v. Ebdane, G.R. No. 167919, 515 S.C.R.A. 720 (S.C., Feb. 14, 2007) (Phil.).

108 Id. 
v. Gov't of the Republic of the Phil. Panel which are related to international law. ${ }^{109}$ The Memorandum of Agreement on Ancestral Domain (MOA-AD) identified as terms of reference, two local statutes (i.e., the Organic Act for the Autonomous Region in Muslim Mindanao and the Indigenous Peoples Rights Act) and several international law instruments (e.g., ILO Convention No. 169 Concerning Indigenous and Tribal Peoples in Independent Countries in relation to the UN Declaration on the Rights of the Indigenous Peoples, and the UN Charter). ${ }^{110}$ The Court however ruled that the MOA$\mathrm{AD}$, in its present form, was inconsistent with the Constitution and laws. ${ }^{11}$

The Court said that the objections against the MOA-AD generally focused on the extent of the powers conceded to the Bangsamoro Juridical Entity (BJE), the entity created under the agreement. ${ }^{112}$ A general idea that unifies the different provisions of the MOA-AD is international law's concept of association. The Court, speaking through Justice CarpioMorales, said:

The nature of the "associative" relationship may have been intended to be defined more precisely in the still to be forged Comprehensive Compact. Nonetheless, given that there is a concept of "association" in international law, and the MOA-AD-by its inclusion of international law instruments in its TOR-placed itself in an international legal context, that concept of association may be brought to bear in understanding the use of the term "associative" in the MOA-AD.

Keitner and Reisman state that [a]n association is formed when two states of unequal power voluntarily establish durable links. In the basic model, one state, the associate, delegates certain responsibilities to the other, the principal, while maintaining its international status as a state. Free associations represent a middle ground between integration and independence.

In international practice, the "associated state" arrangement has usually been used as a transitional device of former colonies on their way to full independence. Examples of states that have

109 Province of N. Cotabato v. Gov't of the Republic of the Phil. Peace Panel, G.R. No. 183591, 568 S.C.R.A. 402 (S.C., Oct. 14, 2008) (Phil.).

$110 I d$.

$111 I d$.

112 Id. 
passed through the status of associated states as a transitional phase are Antigua, St. Kitts-Nevis-Anguilla, Dominica, St. Lucia, St. Vincent and Grenada. All have since become independent states.

Back to the MOA-AD, it contains many provisions which are consistent with the international legal concept of association, specifically the following: the BJE's capacity to enter into economic and trade relations with foreign countries, the commitment of the Central Government to ensure the BJE's participation in meetings and events in the ASEAN and the specialized UN agencies, and the continuing responsibility of the Central Government over external defense. Moreover, the BJE's right to participate in Philippine official missions bearing on negotiation of border agreements, environmental protection, and sharing of revenues pertaining to the bodies of water adjacent to or between the islands forming part of the ancestral domain, resembles the right of the governments of FSM and the Marshall Islands to be consulted by the U.S. government on any foreign affairs matter affecting them.

These provisions of the MOA indicate, among other things, that the Parties aimed to vest in the BJE the status of an associated state or, at any rate, a status closely approximating it. ${ }^{113}$ (Emphasis added)

Moreso, the concept of association is not recognized under the Constitution, says the Court, for it also implies the recognition of the associated entity as a State. ${ }^{114}$ The Constitution does not contemplate any State in this jurisdiction, except the Philippine State. There is no provision for a transitory status towards independence. ${ }^{115}$ Mere concepts animating the agreement, though unsigned, require amendment of the Constitution for validity. ${ }^{116}$ Although the MOA-AD would not amount to an international agreement or unilateral declaration which binds the Philippines, the Court cautioned that the act of guaranteeing amendments was, by itself, already a constitutional violation that rendered the MOA-AD fatally defective. ${ }^{117}$ The aspects of the case on the relation between municipal and international laws, and on indigenous people's rights are discussed, infra.

$\begin{array}{ll}113 & I d \\ 114 & I d \\ 115 & I d . \\ 116 & I d \\ 117 & I d\end{array}$


In miscellany, it was held that the control of movement of considerable foreign currency across borders was included in the UN Convention against Corruption and the UN Convention against Transnational Organized Crime. ${ }^{118}$ In Nicolas v. Romulo, the Visiting Forces Agreement was once again questioned, this time as to a non-surrender agreement contained therein. ${ }^{119}$ The Court still sustained the agreement on similar reasons as Bayan. Magallona decries Nicolas as it "pursues the defense of the VFA by pursuing further the thesis that the United States Government has recognized it as a treaty as required by the Constitution." 120

Vinuya v. Exec. Sec'y, pertained to the issue of whether the State could be compelled to espouse the claims of "comfort women" for official apology and other forms of reparations against Japan before the International Court of Justice and other international tribunals. ${ }^{121}$ The Court held that the Philippines was not under any international obligation to espouse the claims. ${ }^{122}$ The only means available for individuals to bring a claim within the international legal system has been when the individual is able to persuade a government to bring a claim on the individual's behalf. ${ }^{123}$ It is not the individual's rights that are being asserted, but rather, the State's own. ${ }^{124}$ Even the invocation of jus cogens norms and erga omnes obligations would not alter this. ${ }^{125}$

After 2010, the array of questions answered by the Court widened, including matters related to the Law of the Sea, non-surrender agreements, and the character of a national society of the Red Cross. Indeed, courts moved with the times. The Philippine domestic courts have moved from answering questions mainly confined within the laws of war to the present-day issues confronting State sovereignty. It is this postmodernity that is brought before the Court. Judicial review power has expanded with

118 Spouses Dela Paz v. Senate Comm. on Foreign Relations, G.R. No. 184849 (S.C., Feb. 13, 2009) (Phil.).

119 Nicolas v. Romulo, G.R. No. 176051, 578 S.C.R.A. 438 (S.C., Feb. 11, 2009) (Phil.).

120 Magallona, supra note 45, at 19.

121 Vinuya v. Exec. Sec’y, G.R. No. 162230 (S.C., Apr. 28, 2010) (Phil.).

$122 I d$.

123 Id.

$124 I d$.

125 Id. 
the advent of the 1987 Constitution. But, since the 1940s, the backdrop of a hybrid legal system has remained the same.

\section{TREATY INTERPRETATION, HUMAN RIGHTS, AND THE DEVELOPMENT OF DOMESTIC LAW IN LIGHT OF INTERNATIONAL LAW}

As evident in the discussions hitherto, the Court has dealt with questions on the interpretation of treaties, and the treatment of international customary law and international human rights in light of constitutional rules in different periods. Further reflections on these are thus in order.

\section{a. Interpretation of Treaties}

Under the Constitution, no treaty or international agreement is valid and effective, unless it is concurred by at least two-thirds of the entire Senate. ${ }^{126}$ By an act of the legislature, international law norms may be transformed into domestic law, or it may determine the specific terms by which treaty rules are to be applied or enforced as part of domestic law. ${ }^{127}$ Therefore, a treaty then assumes a double character, namely, as a source of international obligations and as domestic law. ${ }^{128}$

How does the Court interpret treaties? The words, intent of the parties, and the object and purpose of a treaty are crucial. But, jurisprudence holds that the cardinal rule of interpretation must involve an examination of the text, which is presumed to verbalize the parties' intentions. ${ }^{129}$

For instance, Senate concurrence on its own does not transform a treaty into domestic law if its provisions have not yet entered into force. ${ }^{130}$ Also,

126 Const. (1987), art. VII, sec. 21 (Phil.).

127 Merlin M. Magallona, A Primer in International Law in Relation to Philippine LaW 49 (1997).

$128 I d$. at 51.

129 Lim v. Exec. Sec'y, G.R. No, 151445 (S.C., Apr. 11, 2002) (Phil.) (“The Convention likewise dictates what may be used as aids to deduce the meaning of terms, which it refers to as the context of the treaty, as well as other elements may be taken into account alongside the aforesaid context.").

130 Magallona, supra note 127. 
generally, only the concurrence is required for a treaty to be valid and effective. Magallona writes that, "the Supreme Court has applied treaties to which the Philippines is a party, as self-executing instruments, requiring no further prerequisite to their effectivity within Philippine jurisdiction." ${ }^{131}$ This is evident in the Tax Convention with Japan, the Paris Convention for the Protection of Industrial Property, the Convention for the Unification of Certain Rules Relating to International Air Travel (Warsaw Convention), and the Convention on the Privileges and Immunities of the Specialized Agencies of the UN. ${ }^{132}$ It is also possible that a treaty itself may provide for its application or enforcement through an enactment of a legislative, executive or administrative act. ${ }^{133}$ Thus, without enactment, the treaty may not be enforced in the Philippines. ${ }^{134}$

Sec'y of Justice v. Lantion lays the rule that all treaties, including the Philippines-United States Extradition Treaty, should be interpreted in light of the signatories' intent. ${ }^{135}$ The Court stated that nothing less than the Vienna Convention on the Law of Treaties, to which the Philippines is a party, provided that "a treaty shall be interpreted in good faith in accordance with the ordinary meaning to be given to the terms of the treaty in their context and in light of its object and purpose."136 Because countries like the Philippines forge extradition treaties to respond to dramatic increase in international and transnational crimes, the treaty calls for an interpretation that will minimize, if not prevent, the escape of an extradited person from the long arm of the law and expedite their trial. ${ }^{137}$ Withal, the Court emphasized that equally compelling factors to consider were the understanding of the parties themselves to the treaty and the general

131 Id.

132 Id. at 54 (citing Marubeni v. Comm'r of Internal Revenue, G.R. No. 76573, 177 S.C.R.A. 500 (S.C., Sept. 14, 1989) (Phil.); La Chemise Lacoste v. Fernandez, G.R. No. L-63796-97, 129 S.C.R.A. 373 (S.C., May 2, 1984) (Phil.); KLM Royal Dutch Airlines v. Court of Appeals, G.R. Nos. L-52153-54 (S.C., Nov. 17, 1980) (Phil.); Aquino, 48 S.C.R.A 242).

133 Id. at 55.

$134 I d$.

135 Lantion, G.R. No. 139465.

136 Id.

137 Id. 
interpretation of the issue by other countries with similar treaties with the Philippines. ${ }^{138}$ The meaning given to treaties by the government departments particularly charged with their negotiation and enforcement is accorded great weight only.

Documents related to a treaty were resorted to aid interpretation. Case in point is $A B S-C B N$ v. PMSI, where the Court ruled that "retransmission" as described in the Working Paper prepared by the Secretariat of the Working Committee on Copyright and Related Rights in relation to the International Convention for the Protection of Performers, Producers of Phonograms and Broadcasting Organizations (1961 Rome Convention), and as defined in the Convention, did not extend to cable retransmission. ${ }^{139}$

On several occasions, the Court had to rule on the meaning of reciprocity or comity in a treaty regulating the practice of professions. In re Garcia held that such a treaty did not apply to a Filipino who seeks to practice his profession in the Philippines even if he was allowed by Spain. ${ }^{140}$ Obviously, the Court referred to the intent of the agreement. In a similar manner, the Warsaw Convention has been interpreted a few times. One such case is Alitalia v. Immediate Appellate Court, holding that the Convention limiting the amount of recoverable damages did not apply where there was a special or extraordinary form of injury. ${ }^{141}$ Hence, it disregarded the literal import of the treaty.

The agreements of the Philippines with the United States on military bases and troops have been interpreted by the court again and again. In 1948, Dizon v. Commanding Gen. held that the waiver of jurisdiction of courts under the Military Bases Agreement covered the area in question in the case. ${ }^{142}$ Petitioners contended that the General Court Martial had no jurisdiction over the alleged offense, which was committed in a place that

138 Id.

139 ABS-CBN Broad. Corp. v. Phil. Multi-Media Sys., Inc., G.R. Nos. 175769-70 (S.C., Jan. 19, 2009) (Phil).

140 In re Petition of Arturo Efren Garcia for Admission to the Phil. Bar Without Taking Examination, 2 S.C.R.A. 984 (S.C., Aug. 15, 1961) (Phil.).

141 Alitalia v. Immediate Appellate Court, G.R. No. 71929, 192 S.C.R.A. 9 (S.C., Dec. 4, 1990) (Phil.).

142 Dizon v. Commanding Gen. of the Phil. Ryukus Command, G.R. No. L-2110, 81 Phil. Rep. 286 (S.C., July 22, 1948) (Phil.). 
was not a base of the US Army within the meaning of the agreement. ${ }^{143}$ But, the Court held that the main storage area outside the base qualified as a "temporary installation" under the same agreement. ${ }^{144}$ In Bayan, the Court was criticized for transporting the meaning of "treaty" to the international plane, shifting the paradigm from the law of treaties under the Constitution to the law of treaties in objective international law, supra. ${ }^{145}$ It was alleged, as above, that Nicolas pursued this defense of the Visiting Forces Agreement. ${ }^{146}$

On the interpretation of treaties to which the Philippines is not a party, in Kuroda, the Court applied the Hague Convention on Rules and Regulations Covering Land Warfare and the Geneva Convention even when it was not a party thereto. ${ }^{147}$ The Geneva Convention was signed only later on. The action was justified on the theory that the conventions were wholly based on the generally accepted principles of international law.

\section{b. Customary International Law Rules: The Incorporation Clause and Monist-Dualist Debate}

The treatment and application of customary international law in Philippine domestic law hinge on the question of whether the Philippines is a monist or dualist State.

The first modern Constitution of the Philippines, or the 1899 Constitution, did not contain any explicit reference to international law. The so-called 'constitutionalism' of international law is traceable to the 1935 Constitution, which established the Commonwealth of the Philippines under American rule. Article II, Section 3 of the said constitution provides that, "[ $t$ ]he Philippines renounces war as an instrument of national policy, and adopts the generally accepted principles of international law as part of the law of the Nation." 148

\footnotetext{
143 Id.

144 Id.

145 Bayan, G.R. No. 138570.

146 Nicolas, G.R. No. 176051.

147 Kuroda, G.R. No. L-2662.

148 Const. (1935), art. II, sec. 3 (Phil.).
} 
For our purposes, the second part of the provision is important. Desierto posits that the intent in relation to this provision apparently affirms the universalist orientation towards fundamental human dignity values and the Philippines' responsible participation in international public order. She cites Aruego:

The second part of this declaration of principle --- the adoption of the generally accepted principles of international law as a part of the law of the Nation --- was borrowed from section 4 of the German Constitution and section 7 of the Constitution of the Republic of Spain.

The intention of the framers of the Constitution was to incorporate expressly into the system of municipal law the principles of international law, the observance of which would be necessary to the preservation of the family of nations which the Philippines was expected to join at the expiration of the Commonwealth period in the Tydings-McDuffie Law.

This provision is a formal declaration of what is considered to be the primordial duty of every member of the family of nations, namely, to adjust its system of municipal law so as to enforce at least within its jurisdiction the generally accepted principles of international law."149

Notably, many cases of international law were decided after the inclusion of the above provision in the 1935 Philippine Constitution. They quoted the provision in detail. For instance, in Kuroda, the Court applied the two treaties even when the country was not a party thereto under the justification that the two treaties were based on the generally accepted principles of international law. ${ }^{150}$

In the 1987 Constitution, the same tenor was included as Article II, Section 2. It reads: "[ $\mathrm{t}]$ he Philippines renounces war as an instrument of national policy, adopts the generally accepted principles of international law as part of the law of the land and adheres to the policy of peace, equality, justice, freedom, cooperation, and amity with all nations." ${ }^{151}$ As to the

149 Diane A. Desierto, A Universalist History of the 1987 Philippine Constitution, 11 Historia Constitutional 427 (2010) available at http://www. historiaconstitucional.com/index.php/historiaconstitucional/article/ download/277/244.

150 Kuroda, G.R. No. L-2662.

151 Const. (1987), art. II, sec. 2 (Phil.). 
intent of the framers of the 1987 document, Bernas writes that it is a reiteration of both the 1935 and the 1973 constitutions. ${ }^{152}$ During the debates, when asked whether "generally accepted principles of international law" was part of statutory law or constitutional law, the sponsor's answer was unclear. Rather, he seemed to suggest that at least provisions of the UN Charter were to form part of both constitutional and statutory law. In the period of amendment, it was clarified that the principles were to be part of statutory law only. ${ }^{153}$

There are opposing views among scholars as to whether this made the Philippines a monist or dualist State. No case law has thus far categorically stated the position of the Philippines. Also, a nother question lingers: What does the phrase "generally accepted principles of international law" mean?

On the one hand, Defensor-Santiago argues that the Philippines is a monist State because of Article II, Section 2 of the Constitution. Cases decided by the Court usually begin by quoting this provision, and then proceeding to apply international law directly, without finding any need to search for an enabling act of Congress. ${ }^{154}$ And, in most cases, the Court did not find any difficulty in reconciling international law with national law. The consequence is that all treaties have the status of national law. A treaty does not need affirming legislation from the Philippine Congress. International law is directly applicable in judicial litigation. Another result is that international law is equal to national law in the hierarchy of norms. In case of conflict, the last in point of time will control. ${ }^{155}$ In adding support to her argument, she stated that principle that the law of nations was part of the law of the land was adopted in the United States, even before the US Constitution was drafted, as it was stated in The Paquete Habana. ${ }^{156}$

On the other, Bernas states that the Constitution manifested its adherence to the dualist theory, and at the same time adopted the incorporation theory, and thereby made international law part of domestic law with

152 Joaquin G. Bernas, The Intent of the 1986 Constitution Writers 75-76 (1995).

153 Id.

154 Defensor-Santiago, supra note 8, at 30.

155 Id.

156 Id. at 31; The Paquete Habana, 175 U.S. 677 (1900). 
regard to customary law and treaties which had become customary law. ${ }^{157}$ In the case of treaties as international law, they become part of the law of the land when concurred by the Senate in accordance with the Constitution, thereby transforming a treaty into binding municipal law. ${ }^{158}$ Thus, treaty law and customary international law are placed on the same level as statutes passed by the Congress. ${ }^{159} \mathrm{He}$ once added that the provision made the Philippines one of the States which make a specific declaration that international law also has the force of domestic law. Similar provisions are found in the Austrian Constitution, Article 9: "[t]he generally recognized rules of international law shall be considered as component parts of the Federal Law," and in Article 25 of the Constitution of the Federal Republic of Germany: "[t]he general rules of public international law are an integral part of federal law."160

According to scholars, the provision has caused confusion in jurisprudence. Llamzon writes that the elements of international law, which become part of Philippine law by incorporation, are not uniformly applied. ${ }^{161}$ The distinction that only customary law "automatically" become part of the law of the land is sometimes blurred in some Philippine Supreme Court decisions. ${ }^{162}$ This is because since treaties become part of Philippine law only by ratification, the principle of incorporation applies only to customary law and to treaties which have become part of customary law. ${ }^{163}$

Magallona adds a different dimension to the debate. According to him, with regard to the internalization of international law, only general international law is to be understood as forming part of the law of the land. ${ }^{164}$ This means not only customary law, but also general principles of

157 Joaquin G. Bernas, An Introduction to Public International LaW 57(2002). 158 Id.

159 Joaquin G. Bernas, The Philippine Constitution for Ladies, Gentlemen AND OThers 12 (2007).

160 BERNAS, supra note 157, at 58.

161 Aloysius P. Llamzon, The Generally Accepted Principles of International Law: Towards a Structurally Consistent Use of Customary International Law in Philippine Courts, 47 Ateneo Law Journal 243 (2002).

$162 I d$.

163 Id.

164 Magallona, supra note 127 , at 36-37. 
law. ${ }^{165} \mathrm{He}$ cites that, at times, the attitude of the Court is not in line with the incorporation clause. For example, in obiter in at least two cases, treaty norms were considered to be covered by the clause. ${ }^{166}$ In Agustin v. Edu, the Court said that the Vienna Convention on Road Signs and Signals was impressed with the character of generally accepted principles, which the Constitution adopted as part of the law of the land. ${ }^{167}$ Magallona opined that, in Marcos v. Manglapus, the Court that quoted certain rights under the International Covenant on Civil and Political Rights, failed to mention that the Philippines was a party to the treaty, but found it necessary to explain that the right to return to one's country was a generally accepted principle of international law which was part of the law of the land. ${ }^{168}$

Aside from the treatment of customary law, several areas are affected by this ongoing debate, like the so-called shifting of concepts between the two spheres of international law and domestic law (as illustrated above). Also, the incorporation or reception of international law into domestic Philippine law can become a problem when international law, whether customary or conventional, comes into conflict with domestic law, whether constitutional or statutory. ${ }^{169}$ It could also affect the application or nonapplication of human rights norms for the Court has often invoked certain human rights norms as custom in its decisions. This trend of a confused Court will reverberate in jurisprudence.

Notwithstanding, through the years, the Court has consistently referred to a definition of international custom ${ }^{170}$ as a source of international law stated in the Statute of the International Court of Justice. It also referred to its two elements: (1) State practice, the objective element; and (2) opinio juris sive necessitates, the subjective element. ${ }^{171}$ It made mention of genocide, war crimes, and crimes against humanity as attaining custom-

$165 I d$.

$166 I d$. at 38.

167 Agustin v. Edu, G.R. No. L-49112, 88 S.C.R.A. 195 (S.C., Feb. 2, 1979) (Phil.).

168 Marcos v. Manglapus, G.R. No. 88211, 177 S.C.R.A. 668 (S.C., Sept. 15, 1989) (Phil.).

169 BERNAS, supra note 157 , at 60.

170 Restatement (Third) of Foreign Relations Law of the U.S. \$102(2) (1987).

171 Id. 
ary status, and some even went further and stated that the prohibition of these crimes had attained the status of jus cogens. ${ }^{172}$

\section{c. Interpretation of International Human Rights Norms in Light of Domestic Constitutional Rules}

International human rights norms, like any other norms in international law, have been always tested as to constitutionality. Many norms have been applied on the strength that they are customary, through the incorporation clause found in the Constitution. For instance, in Mejoff v. Dir. of Prisons, the freedom from arbitrary detention of a stateless person was decided using the incorporation clause in the 1935 Constitution and the provisions of the UDHR. ${ }^{173}$

Evidently, human rights cases in the Philippines commonly take the form of petitions for writs of habeas corpus, or injunctions against the police and military. The cases do not deal with international human rights law, in itself, but with national human rights law found in the Philippine Constitution's Bill of Rights in relation with international human rights law. The latter sometimes influences deportation cases against undesirable aliens and the application by non-nationals for admission to certain professions. ${ }^{174}$

As could be seen from a quick survey of the cases in international law in the past years, human rights, as enunciated in the UDHR, have been the subject of several cases before the Court, such as those that involved the right to political participation, freedom from undue detention and torture, and even violence. ${ }^{175}$

A bifurcation exists, however, as to the treatment and application of civil and political rights, on the one hand, and of economic, social, and cultural rights, on the other. From the time that the Court decided on $R a$ quiza v. Bradford in 1945, ${ }^{176}$ a variety of cases involving civil and political

172 Bayan, G.R. No. 138570.

173 Mejoff, G.R. No. L-2855.

174 Defensor-Santiago, supra note 8, at 275.

175 E.g., Reyes v. Bagatsing, G.R. No. L-65366, 125 S.C.R.A. 553 (S.C., Nov. 9, 1983) (Phil.); Phil. Assoc. of Labor Unions v. Sec'y of Labor, G.R. No. L-22228, 27 S.C.R.A. 40 (S.C., Feb. 27, 1969) (Phil.).

176 Raquiza, G.R. No. L-44. 
rights had been decided. Deportation as inherent to sovereignty has been asserted. ${ }^{177}$ But, aliens are protected by the UDHR and the Bill of Rights of the Constitution, particularly as to civil and political rights. ${ }^{178}$

Desierto writes that over the last two decades since the promulgation of the 1987 Constitution, the Court has issued writs and/or resolved cases on fundamental civil liberties and basic constitutional rights guarantees using its expanded judicial review power, including, among others: nullifying administrative rules and regulations issued by the executive department that contravened the constitutionally-mandated agrarian reform program; affirming the constitutional right to a fair and a speedy trial; affirming a lower court judgment finding the government's use of arrest, detention, or deportation orders to be illegal and arbitrary; enjoining the military and police's conduct of warrantless arrests and searches, "aerial target zonings" or "saturation drives" in areas where alleged subversives were supposedly hiding; declaring search warrants defective and the ensuing seizure of private properties to be illegal; acquitting a person whose conviction for murder was based largely on an inadmissible extrajudicial confession (obtained without the presence of counsel); upholding the dismissal of a criminal charge on the basis of the constitutional right against double jeopardy; acquittal of a public officer due to a violation of the constitutional right of the accused to a speedy disposition of his or her case; prohibiting the compelled donation of print media space to the Commission on Elections without payment of just compensation; and prohibiting governmental restrictions on the publication of election survey results for unconstitutionally abridging the freedom of speech, expression, and the press. ${ }^{179}$

This is no perplexity since civil and political rights are found in the Bill of Rights, and the Bill is self-executing. As emphasized earlier, the Court is in reality not applying international law, but domestic law. A mirror study of the Bill and the International Covenant on Civil and Political

177 Harvey v. Defensor Santiago, G.R. No. 82544, 162 S.C.R.A. 840 (S.C., June 28, 1988) (Phil.).

178 Borovsky v. Comm'r of Immigration, G.R. No. L-4352, 90 PhiL. Rep. 107 (S.C., Sept. 28, 1951) (Phil.); People v. Chan Fook, G.R. No. L-16968, 42 PhiL. Rep. 230 (S.C., Oct. 6, 1921) (Phil.).

179 Diane A. Desierto, Justiciability of Socio-Economic Rights: Comparative Powers, Roles, and Practices in the Philippines and South Africa, 11 Asian-Pacific Law \& Policy Journal 114, 129-30 (2009). 
Rights readily reveals the commonality in each of them. The ramification is that civil and political rights could be pleaded and decided upon by the domestic court.

Meanwhile, economic, social and cultural rights are nowhere found in the Bill of Rights. Although they exist in other parts of the Constitution, many of them appear not to be self-executing. That being said, as a general rule, the provisions of the Constitution are still considered self-executing, and do not require further legislation for their enforcement. This is because if they are not treated as self-executing, the mandate of the fundamental law can be easily nullified by inaction of Congress. However, some provisions have already been categorically declared by the Court as non-selfexecuting based on their tenor. ${ }^{180}$ The 1987 Constitution's provisions on socio-economic rights are found in Article II (Declaration of Principles and State Policies), others in Articles XIII (Social Justice and Human Rights), XIV (Education, Science and Technology, Arts, Culture, and Sports), and XV (The Family). ${ }^{181}$

In the 1990s, the justiciability of economic, social and cultural rights was decided in a landmark case. In Oposa v. Factoran, Article II, Section 15 (right to health) and Section 16 (right of the people to a balanced and healthful ecology) formed the constitutional basis for standing in a class suit seeking the cancellation of Timber License Agreements. ${ }^{182}$ The undivided Court ruled that while the right to a balanced and healthful ecology was found under the Declaration of Principles and State Policies and not under the Bill of Rights, it did not follow that it was less important than any of the civil and political rights enumerated in the latter. ${ }^{183}$ Such a right belongs to an entirely different category of rights for it concerns nothing less than self-preservation and self-perpetuation, aptly and fittingly stressed by the petitioners, the advancement of which may even be said to predate all governments and constitutions. ${ }^{184}$ Another one is Laguna Lake Dev.

180 Tondo Med. Ctr. Emps. Ass'n v. Court of Appeals, G.R. No. 167324 (S.C., July 17, 2007) (Phil.).

181 Desierto, supra note 179, at 134.

182 Oposa, G.R. No. 101083.

183 Id.

184 Id. 
Auth. v. Court of Appeals. ${ }^{185}$ The Court asked, "[h]ow do we strike a balance between environmental protection, on the one hand, and the individual personal interests of people, on the other?"186

A string of other cases followed in recent times with regard to the health of the people, and the environment. The Court seems to take a rightsbased approach to these topics. In Metro Manila Dev. Auth. v. Concerned Residents of Manila Bay, the Court ordered concerned government agencies to coordinate the cleanup, restoration, and preservation of the water quality of Manila Bay in line with the country's development objective of attaining economic growth consistent with the protection, preservation, and revival of marine waters. ${ }^{187}$ Roma Drugv. Reg'l Trial Court of Guagua, Pampanga recognized the constitutional right to health, and declared that the provision of a law classifying "unregistered imported drugs" as "counterfeit drugs" and criminal penalties against its importation deprived Filipinos to choose a less expensive regime for their health care. ${ }^{188}$ In these cases, the Court considered the language of the provisions that animate the economic, social, or cultural right involved. It had to be authoritative-a mandate or an imperative-and self-executing in this regard.

Recently, the Court's decisions on human rights cases also focus on writs for the protection of the right to life, liberty and security due to the issuance of the writs of Amparo, among others. ${ }^{189}$ For example, in Razon $v$. Tagitis, the Court reflected on the nature of Amparo - a protective remedy against violations or threats of violation against the rights to life, liberty and security. ${ }^{190}$ It embodies, as a remedy, the court's directive to police agencies to undertake specified courses of action to address the disappearance of an individual. ${ }^{191}$ It does not determine guilt or pinpoint criminal culpability for the disappearance; rather, it determines responsibility, or at

\footnotetext{
185 Laguna Lake Dev. Auth., G.R. No. 110120.

186 Id.

187 Metro Manila Dev. Auth. v. Concerned Residents of Manila Bay, G.R. Nos. 17194748 (S.C., Dec. 18, 2008) (Phil.).

188 Roma Drug v. Reg'l Trial Court of Guagua, Pampanga, G.R. No. 149907 (S.C., Apr. 16, 2009) (Phil.).

189 See Razon v. Tagitis, G.R. No. 182498 (S.C., Dec. 3, 2009) (Phil.).

190 Id.

191 Id.
} 
least accountability, for the enforced disappearance for purposes of imposing appropriate remedies to address the disappearance. ${ }^{192}$ Other equally important writs may now issue, such as those on the environment and the right to information, affording the respect, protection, and fulfillment of rights. The rights of collective minorities have been also passed upon. In obiter, Province of North Cotabato pondered on the possibility of regarding the UN Declaration on the Rights of Indigenous Peoples as embodying customary law. ${ }^{193}$

Truly, a process of transformation implicitly underlies the whole framework of the 1987 Constitution. This means that to bring about a regime of comprehensive human rights is the function of the entire political system established by the Constitution and the individual, and the collective efforts of the citizens to realize human rights in their social life is a supreme constitutional responsibility. The provisions on human rights in the Constitution constitute the vehicle by which the people must transform themselves into a politically-conscious force and an agency for comprehensive democratic changes. ${ }^{194}$ And, international law is part of that process.

\section{d. Impact of International Legal Norms on the Development of Domestic Law}

There are various ways in which international legal norms have aided the development of domestic law. Firstly, as stated above, the Court on occasion made use of binding international law to settle domestic problems. Relevant to this are the cases of Mejoff and Agustin. International law, therefore, can be used by the Philippine Court to settle domestic disputes in much the same way that it would use the Civil Code, the Penal Code, or other laws passed by the Congress. ${ }^{195}$ Secondly, although not a party to the convention or treaty, the Court has used an underpinning treaty to resolve a legal question. This is evident in Kuroda. Corollary to this, it is reasonable to expect that the activist Court, reinvigorated by the not-

192 Id.

193 Province of N. Cotabato, G.R. No. 183591.

194 Merlin M. Magallona, International Law Issues in Perspective 150-51 (1996).

195 BERNAS, supra note 157 , at 58-59. 
so-distant rapture of the political system, will play a role in appropriating international legal norms to develop the domestic.

Conversely, it had been suggested also that judgments of the Philippine domestic court could be of considerable practical importance for determining the right rule of international law. The Court said in Gibbs: "[a] decision of the Supreme Court of a small Republic of the Philippines is as much a source of International Law as a decision of the great Republic of the United States of America."196

Procedurally, due to the Philippines' incorporation clause, the cumulative effect combined with the rule on judicial notice, is that no proof at all is needed for the application of generally accepted principles of international law. This results in ease and convenience for the courts of law with regard to the probative value of international legal norms. ${ }^{197}$

\section{CONCLUSION}

There is a confluence of the two streams of national law and international law in the Philippine Court. The relation between them is complex, and at times, perplexing. This holds true from the earliest times when the Philippine Court dealt with international law in the 1940s, where much of the questions centered on the laws and exigencies of war, to the present where postmodernity necessitates ruling on various areas of law, including human rights and technology. The Supreme Court of the Philippines, sitting as a national court, invariably applies domestic law, and tries to deliver its duty of fidelity to the Constitution of the Philippines as the fundamental law via the power of judicial review. Where concepts, postulates, and theories of international law form part of the domestic, the Court applies them as domestic law.

However, there have been, at several points in time, divergence in and out of the Court as to what really is incorporated into Philippine law from international law. Further, the shifting of ideas from the two planes of law has been noted. The relation between the two in the application of customary law, human rights norms, and the development of domestic law through the enrichment thereof by international law, has been deliberatively vibrant and alive. These operate within the framework of a legal system that is unique, unusual, and evolving in time.

196 Gibbs, G.R. No. L-1494.

197 Magallona, supra note 127, at 39. 